\title{
The Application of Bakhtin's “Heteroglossia” to Tennessee Williams's A Streetcar Named Desire
}

\author{
Raja Khaleel Al-Khalili*
}

English Department, PO BOX 1987, Irbid, Jordan

Corresponding Author: Raja Khaleel Al-Khalili, E-mail: raja@hu.edu.jo

\section{ARTICLE INFO}

Article history

Received: August 23, 2018

Accepted: October 21, 2018

Published: December 28, 2018

Volume: 9 Issue: 6

Advance access: November 2018

Conflicts of interest: None

Funding: None

Key words:

Bakhtin,

American Literature,

Heteroglossia,

Tennessee Williams,

Modern Drama,

Racism,

Said

\begin{abstract}
Tennessee William in A Streetcar Named Desire shows the struggles of middle class Americans as they undergo socio-ideological contradictions. The research applies Bakhtin's theory that is defined in his book The Dialogic Imagination and specifically applies heteroglossia on A Streetcar Named Desire. Edward Said's concept of “orientalism" is useful because Said's concept explains the link between the problems of American society and its heterogeneous structure. The play explores the effects of diversity on American society. The characters in the play perceive their lives as a reflection of their linguistically diverse surrounding which is closely tied to the American experience. The play also shows how diversity is seen as a negative presence in America. The research shows how the play is heteroglot by examining the characters' stories. The play's narratives reflect the two faces of how the middle class white Americans see the diversity of American culture. The research recommends that the analysis of plays based on the concept of "heteroglossia" could yield more insight into the other plays by Williams.
\end{abstract}

\section{INTRODUCTION}

The article examines the play $A$ Streetcar Named Desire by Tennessee Williams as a narrative of the multicultural nature of American society and its many contradictions. The writer shows the struggles of middle class Americans in a society that praises the diversity of culture. The research applies Bakhtin's theory that is defined in his book The Dialogic Imagination and specifically uses the concept of "heteroglossia" to A Streetcar Named Desire. Furthermore, the researcher relies on Edward Said's concept of "orientalism" because it explains the link between the problems of American society and its heterogeneous structure. The play portrays diversity as a negative presence in America. The research aims to show how the play is heteroglot by examining the character' stories and how the writer uses many people from different backgrounds to illicit empathy from the readers towards the impoverished whites of America.

Mikhail Mikhailovich Bakhtin introduces in his book The Dialogic Imagination (1957) the concept of 'Heteroglossia,'which he considers essential in determining the artistic value of any literary work. He defines heteroglossia in a chapter entitled 'Discourse in the Novel' as "another's speech in another's language, serving to express authorial intentions but in a refracted way" (324). Bakhtin further argues in his book that language in this and any other moment in history is heteroglossic "represent[ing] the co-existence of socio-ideological contradictions between the present and the past..." (291). Bakhtin believes that the modern novel is the best genre to represent heteroglossia. "It is precisely the diversity of speech, and not the unity of normative shared language, that is the ground of style" (Bakhtin 308). However, plays which rely heavily on narrative can also display "heteroglossia" because a dramatic work concentrates on giving a traditional framework of a narrative in performance. Since its publication, Bakhtin's The Dialogic Imagination received enormous criticism because of Bakhtin's revolutionary ideas.

The concept of "Heteroglossia" yields rich and critical readings. Goldman, for example, applies heteroglossia in an article entitled, "Language, Satire, and Heteroglossia in the Cena Trimalchionis." Goldman examined language, satire and heteroglossia in the novel Cena Trimalchionis and found that the novel displays a multiplicity of voices that are essential in showing the theme (49-65). Dr. Nyasha Mboti in his article "Heteroglossia in G.H. Musengezi's The Honourable MP" (178-198) illustrates how heteroglossia functions 
in G.H. Musengezi's satirical play The Honourable MP. Therefore, the concept can also be applied to Tennessee Williams' play A Streetcar Named Desire because of the nature of the cosmopolitan city of New Orleans which is the setting of the play. The city provides a panoramic view of modern American individuals and is a deliberate choice made by the writer. The play is an investigation of the stereotypical groups of individuals found in American cities. It also has a list of rounded characters because the author wants to shed light on the diversity and polyphonic nature of American society. The present study uses Bakhtin's concept of "heteroglossia" along with Edward Said's concept of "orientalism" to show the thematic link between the social problems of American society and its heterogeneous structure.

According to Gary Kim, Bakhtin is the philosopher of human communication because Bakhtin views the world as "polyglossic or multi-voiced since every individual possesses their own unique world view which must be taken into consideration through dialogical interaction." Kim argues that Bakhtin's heteroglossia denotes "multi-vocality and multi-culturalism" (54). Moreover, according to Bakhtin, each unique voice "has a historical meaning attached to it since heteroglossia also refers to past and present meanings co-existing in the same language" (55). Kim also states that "Throughout his work, Bakhtin constantly theorizes that everything considered to be a work of art, such as literature, orients itself to multi layered expression and communication towards its audience (54). The conflicting voices of the American public in modern drama are best described as heteroglossic. The current research shows how the play reveals the life struggles of middle class Americans as they undergo socio-ideological contradictions. The research utilizes Bakhtin's theory that is defined in his book The Dialogic Imagination and specifically applies heteroglossia on A Streetcar Named Desire. The play is an example of a drama that explores diversity. The characters in the play perceive their lives as a reflection of their surroundings which exhibits different languages that are closely tied to their experiences and in return shape their own destiny. The play is heteroglot because every time the characters meet, they build a new discourse.

Bakhtin defines "heteroglossia" in the Dialogic Imagination, as a form of verbal communication whose essence lies in the fact that "within the arena of almost every utterance an intense interaction and struggle between one's own and another's word is being waged" (354). Valerij Tjupa states in "The Living Handbook of Narratology" that an individual then "operates not with language as an abstract regulatory norm, but with a multitude of discourse practices that form in their totality a dynamic verbal culture belonging to the society concerned". Jan Blommaert in his book Discourse believes that language differs from one context to another. If a character aims at conveying a certain message, they should "mobilize" what is "the most (denotationally) adequate, contextually appropriate, semiotic means to do so, hoping that the interlocutor will follow [their] directions of contextualization" (67). Therefore, linguists and critics agree on the importance of understanding any speech act as related to the context in which it is produced.
Bakhtin also faced criticism for his views because he builds systems that are open ended. In "In Theory Bakhtin: Dialogism, Polyphony, and Heteroglossia," Andrew Robinson states that "[a]ccording to Michael Holquist, Bakhtin is a system-builder, but not in the sense of methodological closure. Rather, his system consists of open-ended connections, and refuses to view issues in isolation." Therefore, according to Bakhtin, any literary work should be studied as a multiple layer of meanings, which is true. Bakhtin is essential, in my opinion, in understanding the dialogic nature of the novel; events, characters, dialogues, and point of views may not be interpreted in isolation. Characters use language to accomplish a desired function in different contexts. Contexts contribute in the meaning of language used because different contexts demand different languages and languages are loaded with hidden messages and ideas. When an individual interacts with another in a certain context, they establish a unique language which communicates to both of them. Language occurs with accordance with something else. Andrew Robinson states in his article "In Theory Bakhtin: Dialogism, Polyphony, and Heteroglossia" that language is "being and co-being". Dialogues require at least two to be considered a dialogue. It cannot occur in isolation. Robinson also states that "[e]verything is said in response to other statements and in anticipation of future statements". Therefore, the fictional setting of the literary work is an important factor in understanding the work itself.

\section{ANALYSIS}

Tennessee Williams constructed the framework of his play to provide each character with a unique voice. Williams points out to the readers how the inability to communicate with different people is Blanche's problem with the world. The play provides a framework that allows different voices to interact and be heard which is the most important requirement for a work to be considered as displaying heteroglossia. This interaction permits each individual to express his own ideas and present his own view of the world. Williams achieved heteroglossia by using different social classes in his list of characters. Andrew Robinson in his article "In Theory Bakhtin: Dialogism, Polyphony, and Heteroglossia" claims that "[i]nstead of a single objective world, held together by the author's voice, there is a plurality of consciousnesses, each with its own world. The reader does not see a single reality presented by the author, but rather, how reality appears to each character." Williams was innovative and creative because he introduced multiple stories in the play. The characters have already dropped social boundaries that limit their communication in daily life is dropped and they interact and express themselves freely and thus reflect Bakhtin's idea of how "The motif of meeting is after all impossible in isolation..." (Bakhtin 97).

The structure of A Streetcar Named Desire notably breaks the traditional narration of focusing on one character to achieve a heteroglot play. The main character Blanche continues to break the traditional framework of the play by narrating other people's stories. This closeness and break from tradition can be seen in the unheroic acts of Blanche 
because the author wanted a more realistic portrayal of the contemporary scene. Virginia Cope, for example, stresses the importance of the multi-ethnical dimension of the play as it is presented for a modern audience. The Broadway production of the play by Stephen Byrd in 2012 revealed the importance of the diversity of the cast because the black and Hispanic actors inspired the audience to see the broad spectrum of meanings the play has for the public. Cope also considers that the typical strong responses from critics proved to be irrelevant and that the play should be produced with a multiethnic cast (493-512). Thus, part of the success of the play lies in its diverse characters and the setting that allows diversity.

Bakhtin further emphasizes the role of all the characters in the narrative. Characters are irreplaceable because each one plays an important role in the sequence of events and each has his/her unique voice. Without one character, the whole plot changes and events rearrange. Even in different situations in the narrative, characters change their voices because of the change in events. The characters communicate directly to the readers/spectators through dialogue. Moreover, the diverse voices differ from past times to modern times. This is one feature of the heteroglot narrative as Bakhtin argues "represent[ing] the co-existence of socio-ideological contradictions between the present and the past..." (291). Therefore, the form permits different standpoints on the stories and since truth is major theme in the narrative, each character has a truth and hence to understand the narrative, the reader/spectator should comprehend and consider this different background of the characters. This recognition helps the characters better articulate their utterances and convey their unique voice. It also helps modern readers perceive and live in the world. Blanche and her sister, Stella, recognize their status and position in the play and they seek sympathy from the reader/spectator because truth is relative. Williams' appeal to the American public can be attributed to his catering to different voices as there have been multiple dramatizations of his plays such as Cat on a Hot Tin Roof, Camino Real, Not about Nightingales, Sweet Bird of Youth in addition to A Streetcar Named Desire (Raymond, 1999:89-92).

The realism of the multi-ethnical characters and their relationship to the American political state is clearly illustrated in the play. The play's portrayal of a Southern woman's downfall from a life of wealth to bankruptcy is used to invoke sympathy from the modern readers/spectators. However, it is not only her financial state that is under scrutiny, but also her social and psychological well-being. The beautiful Blanche Dubois moves from her luxurious family home to the slums of the multiracial city of New Orleans, which her sister has embraced wholeheartedly. Even though she tries to disengage herself and her sister from the ambiance of the cultural stagnation of the city she ultimately loses the battle and is raped and sent to an asylum. The play reminds it audience that the American social and political worlds is set in a contrast and opposition with the old and the new, South and North, East and West and at the same time reveals a dark image of America as Williams believes that American society is corrupt.
In fact, Williams considers the city as the hub of destruction and comes to the conclusion that cities are not safe sanctuaries for vulnerable whites. The city moves the characters to a survival mode and readers are presented with a narrative that brings man closer to a natural world which favors certain individuals over others. Williams mourns the past of the lost aristocracy of whites in America, and he bemoans the present because the whites have succumbed to the conditions imposed on them. The readers/spectators are left with an impression that the future is only going to be bleak. Therefore, the play prompts the readers into a revelation that the city operates as a unit and functions under a single dominant falsehood of embracing a multicultural existence. The opening scene reveals a two-story apartment building in the slums of the city ironically called the Elysian Fields. Williams presents the story of the American family in a way that creates a sense of wonder because there is a domestic world that is deeply connected to American myth. The description is poetic as it states the morbid state of the scene: "The section is poor but, unlike corresponding sections in other American cities, it has a raffish charm. The houses are mostly white frame, weathered grey, with rickety outside stairs and galleries and quality ornamented gables." (2300). As carefully constructed in the stage descriptions and later demonstrated in the play, Williams focused on the incongruity of the people and the place.

The crowded place shows different ethnicities in one scene that recalls a surrealistic and nightmarish story. The streets are obviously dominated by a black presence because there is jazz music heard from the bars and Eunice, the white woman who owns the building is conversing with a "Negro Woman." There are immigrants in the scene because Stanley Kowalski appears with his friend Mitch. The appearance of Blanche in white and neatly dressed appears incongruous to the place and is emphasized by her inability to understand her position in her sister's home. The thought that Blanche had to take a streetcar named "Desire" sheds light on her "desire" to be there. The symbolic nature of the word puzzled critics on its significance. Blanche had to take two cars in order to reach her sister and one of them is "Cemeteries", which emphasizes the theoretical nature of desire (Thomières 374-391). Williams evokes ties between the ruins of Blanche and her memories. The repositories of a ruin translate into a complex cultural narrative open to multiple interpretations. Williams takes up the ruin motif to convey the density of the political and social ideas that were shaping America. He also casts his protagonist as a victim of the expansive modernizing cities that expose the failure of such multiethnic projects in accommodating diversity. The play is centered on a conflict that shows the social cost of a disharmonious setting. The impoverished city slum is not only a reminder of a past forgotten, but is also a glimpse of a future that carries the same features of an unpleasant present.

Williams leaves nothing to chance and makes a political statement demonstrating the early kind of adjustment that many Americans were taking for a different way of life. Therefore, memory plays an important role in the play. Blanche's memory serves to be an example of a collective 
memory of the southern whites. In Blanche's remembrance of the past, there appears a total recall of moments of repression as in the example of her memories of her husband. In addition, there are moments of complete denial because she believes that she had not contributed to the demise of the family estate. There are also moments of amnesia especially when it comes to financial matters such as in the encounter with Stanley and she becomes totally angry. Williams seems to have a colonial perspective in mind because in a way Blanche appears as a phantom of the past who is dressed in white and representing high culture who is forced to suffer cultural decay which enhances both her status individually and collectively.

Williams wanted to point out to his readers and the audience that cities as constructed at the present time cannot yield any positive outcomes. The city can become a place of sanctuary if it comes closer to the natural existence and ensures the survival not only of traditions and places but also of the white people. If the city is a desecrated and abject place of a displaced group of individuals, then one should expect a cultural waste. Therefore, no wonder that there are characters who are diabolical. As the beginning scene in the play indicates: "In this part of New Orleans you are practically always just around the corner, or a few doors down the street, from a tiny piano being played with the infatuated fluency of brown fingers" (2301). The constant question that Williams raises is how one expects any aesthetic pleasure or reform in a place that has no visual or conceptual unity neither in terms of place nor of people. Even the idea of assimilation draws only social and moral conclusions on its efficacy.

It is difficult to miss Williams's negative portrayal of other ethnicities in the play. In fact, one could detect a similar attitude in Joseph Conrad. Joanna Kurowska in "Colonialism in the French Quarter: Tennessee Williams and Joseph Conrad" focuses on the similarities in both authors works and states that: "Williams's brief references to Conrad do attest to his knowledge of the author of Heart of Darkness, not surprisingly, since Conrad made a significant intellectual impact upon the U.S. reading audience during the 1920s and 1930s - Williams's formative years" (110). As Kurowaska points out there are correspondence in terms of both authors in numerous works and most notably in A Streetcar Named Desire. The various symbols used in Conrad's Heart of Darkness including the river, jungle, and the drums are employed in the play (116). However, the playwright is not only influenced by Conrad, Williams is also making a political statement concerning American domestic politics.

The American political scene in the early twenties was one that can be described as one of dramatic change because more people from various ethnicities were moving to the cities. There were people who left farming that was in a state of poor decline to the cities where many individuals were very quickly accumulating wealth at an unprecedented rate. Amidst the rise in economic stature there was a moral decay that took over many individuals. Therefore, many groups saw a necessity in the reform of American social and cultural state. As an example, there appeared some groups who focused on moral reform in terms of the family unit.
The Woman's Christian Temperance Union and Anti-Saloon campaigned to prevent alcohol from being legally sold to individuals (Boyer 76). The purpose of such campaigns was to enlighten society on the moral decline that was effecting many families throughout the country and more particularly the lower classes. Williams in the play seems to reflect on social issues that were permeating the American scene and the playwright is focusing on the human compassion in dealing with the family and the shift in the play does at certain moments investigates the lives of both Eunice and Stella since they both have to endure the effects of their abusive alcoholic husbands. The play continues in the same provocative and deeply committed social significance. In Scene Three which signifies "The Poker Night," Blanche discusses her work as a school teacher stating that her job was to "instill a bunch of bobbysoxers and drugstore Romeos with reverence for Hawthorne and Whitman and Poe" (2320). The intellectual thought, however, is disrupted by the violent domestic brawl brought on by alcoholic consumption. The audience find themselves attracted to the linguistic playfulness and reliance on the colloquial and the educated dialects of the American public to open possibilities of meaning which provides the writer with a triumph of achievement. Especially effective are the powerful images that substantiate the feelings of strangeness and address the importance of challenging certain beliefs and practices prevalent among individuals.

The play's ironic humor entice the audience's imagination. The heroine of the play and the other characters appear as adolescents who are straining to cut ties with the past and embark on a new identity. Williams influence on other writes can be due to his insistence on the fluidity in a play. As Arthur Miller stated in the impact that the play had in helping him write Death of a Salesman:

With Streetcar, Tennessee had printed a license to speak at full throat, and it helped strengthen me as I turned to Willy Loman, a salesman always full of words, and better yet, a man who could never cease trying, like Adam, to name himself and the world's wonders. I had known all along that this play could not be encompassed by conventional realism, and for one integral reason: in Willy the past was alive as what was happening at the moment, sometimes even crashing in to completely overwhelm his mind. I wanted precisely the same fluidity of form (Qtd in Baym, 2418).

Moreover, the fluidity on stage was an integral part in the success of both plays. The team that Miller employed in the directing and stage design also worked with Williams (Baym 2418). Later productions of the play as well as the motion picture adaptation had both positive and negative reviews. Critics have studied numerous theatrical productions of the play put on stage by various directors and notable a stage version directed by Sheila Daniels at the Intiman Theatre in Seattle, Washington and sheds light on the play's popularity (Berson, 110-113). It is the success of the stage that led to the international recognition of the play. The professional relationship and collaboration with not only directors but also with the cast helped promote the play's appeal. The special relationship between the playwright and the leading actress Tallulah Bankhead is often emphasized by critics as essential 
in understanding the play as well. They shared the Southern heritage and the public regarded both of them as popular cultural icons. Moreover, Bankhead's portrayal of the character Blanche in Williams' play showed a closeness of perception by the leading actress and the playwright on the themes intended in the play (Fisher, 52-72). Therefore, Williams was interested in the background of his characters.

The impact of the racial implications in the play include a description of the physical characteristics of the major and minor characters. Blanche and her sister are both racially described as fragile and sensitive in manners, while Stanley and the others are described as more brutish in terms of physique and manners. The purpose of the description is to enhance the thematic sympathy with the white characters who appear to a large extent as victims in the play. The future of the major character and her sister invokes the possibility of classifying the play as a tragedy. Even though critics have predominantly classified the play as a tragedy, the play does not fit under classical Aristotelian definition of the concept. Therefore, critical views vary on the type of tragedy that appropriately describes the play (Crandell 93). Nevertheless, the play emphasizes the tragic nature of the lives of modern individuals divided by the multiple demands of personal as well as social obligations.

There exists in Blanche's financial problems a social responsibility. She has a duty to maintain a balance between the personal and materialistic needs which are imposed on individuals and a modern economic system that was quickly progressing with a sense of imbalance between its materialistic development and the welfare of the society and the environment. The play is sympathetic towards its heroine Blanche because as she states the responsibility of losing their farm began earlier as other members of the family have neglected the estate and gradually left it in a state of a decline. Therefore, the responsibility is intergenerational and the actions of a previous generation have consequences on the next. However, the blame is not totally specific to individuals as the source of the problem. The play makes it clear that it is related to the government and their lack of involvement in the private sector. The doctrine that the United States federal government traditionally employed was one influenced by the concept of the "laissez-faire." However, the public's attitude towards government involvement saw a change, especially during the late nineteenth century, to regulate the domestic market. As depicted in the play, the stock market crash of 1929, left a deep impact on people with small businesses and farmers and they complained that the federal government did not relieve them. Eventually, many American farmers in the South deserted their farms and were left with enormous debts.

Traditionally, the American South, has a culture that is different from the rest of the country because it has a unique history which shaped its identity. The southern economy which relied on agriculture faced enormous problems in the antebellum period and remained conservative and stratified according to land ownership. Therefore, the spectators in the play observe that Blanche in spite of her poverty is still determined to maintain her lifestyle and is detached from her surroundings.
Williams assigns roles to other multiracial and ethnic groups and uses them as a starting point in highlighting American social and economic problems. The play addresses ethnical tensions that are found in American life and tries to bridge them with a new concept of national identity by highlighting the points of strength and weaknesses. Even though the protagonist does implicit sympathy from the audience, the playwright considers the broader political perspective of the concept of American democracy and serious problems that underlie the American experiment to others who are victims as well because they are living in the slums.

The issue of ethnic diversity in the play reflects the conflicts prevalent in American society which resurfaces not only in literature, but also in real life. Similar to most ethnic conflicts, the source of the problems has many aspects political, economic and definitely social factors. Ultimately, the American problem becomes an individual case as members of different groups fight for positions and resources in society. Moreover, the struggle may or may not take on a violent appearance. In most multiethnic societies, the struggle is often between various groups. As the play demonstrates, the source of ethnic problems is rooted in hatred that is ingrained in the cultural memory of many individuals. The characters in the play are reminders of the rooted social practices among many individuals that are a symptom of an American problem. The everyday habits of people affect national aspirations towards a better understanding of the self and others.

\section{CONCLUSION}

To sum up, the research applied Bakhtin's concept of heteroglossia to the play A Streetcar Named Desire by Tennessee Williams. The concept is useful because it emphasizes the importance of a critical investigation on how a writer uses multiplicity of voices in a work of literature to arrive at social themes. It is especially helpful in its application to Williams' A Streetcar Named Desire. The multiplicity of voices and different socio-ideological contradictions of different characters were used to create a sequence of events that revealed the problems of a multicultural American society. Williams succeeded in his multicultural narrative to reveal the social practices that are not discussed openly in America. The play is a reflection of everyday life that is full of a multiplicity of voices and Williams was successful in creating a play close to a "real" America. The various characters show the audience that in American cities there exists an underground battle of ethnic survival. According to Bakhtin, the ability to create a work of art that displays society with all its intricacies is a true mark of genius. Williams succeeded in showing the trap that American individuals living in a multicultural society fall into when they live in an endless chain of causes and effects in their society resulting in doubt, guilt, and defeat.

\section{REFERENCES}

Bakhtin, M.M. "Discourse in the Novel". In Rivkin, Julie and Michael Ryan (eds). Literary Theory: An Anthology. Blackwell: Blackwell Publishing, (2004): 674 - 686. 
Bakhtin, M. M. The Dialogic Imagination: Four Essays. Caryl Emerson and Michael Holquist (trans.) Michael Holquist (ed). Austin: Texas University Press, 1981.

Baym, Nina. The Norton Anthology of American Literature. New York: Norton, 2013.

Boyer, P. American History: A Very Short Introduction. Oxford: Oxford UP, 2012.

Berson, Misha. "What Does It Take to Keep 'Streetcar' on Track?" American Theatre. 25.8 (2008): 110-113.

Cope, Virginia H. "A Multiethnic Streetcar Named Desire: We've Had This Date from the Beginning." Modern Drama. 57.4 (2014): 493-512.

Crandell, George. "Beyond Pity and Fear: Echoes of Nietzsche's "The Birth of Tragedy" in Tennessee Williams's "A Streetcar Named Desire" and Other Plays. Southern Quarterly. 48.4 (2011):91-107.

Fisher, James. “'Divinely Impossible': Southern Heritage in the Creative Encounters of

Tennessee Williams and Tallulah Bankhead." Southern Quarterly. 48.4 (2011): 52-72.

Goldman, Max L. "Language, Satire, and Heteroglossia in the Cena Trimalchionis." Texas Tech University Press, 35.1(2008):49-65.
Kim, Gary. "Mikhail Bakhtin: The Philosopher of Human Communication." Totem: The University of Western Ontario Journal of Anthology 12.1 (2004): 53-62.

Kurowska, Joanna. "Colonialism in the French Quarter: Tennessee Williams and Joseph Conrad." Southern Quarterly 50. 2 (2013): 109-122.

Mboti, Nyasha. 'Heteroglossia in G.H. Musengezi's The Honourable MP”Critical Arts 28.2(1984):178-198.

Raymond, Gerard. "Tennessee Waltzes On." Advocate 795 (1999): 89-92.

Robinson, Andrew. "In Theory Bakhtin: Dialogism, Polyphony, and Heteroglossia." Ceasefire Magazine (2011). < https:// ceasefiremagazine.co.uk/in-theory-bakhtin-1/>Web. 6 March. 2016.

Thomières, Daniel. "Tennessee Williams and the Two Streetcars." Midwest Quarterly. 53.4 (2012): 374-391.

Tjuba, Valerij. (2012). "Hateroglossia”. The Living Handbook of Narratology. Interdisciplinary Center for Narratology, University of Hamburg. < http://wikis.sub.uni-hamburg. de/lhn/index.php/Heteroglossia >Web. 6 March. 2016.

Williams, Tennessee. A Streetcar Named Desire. In Nina Baym. The Norton Anthology of American Literature. New York: Norton, 2013. 